\section{Radoica Luburić*}

\section{Crisis Prevention and the Coronavirus Pandemic as a Global and Total Risk of Our Time}

\begin{abstract}
The Coronavirus pandemic, as a global and total risk of our time, has imposed the need for a more complete and comprehensive review of existing approaches to crisis prevention and preventive management in general. This crisis also pointed to some shortcomings in quality management, risk management and change management, which had not been removed in a timely and adequate manner in more stable conditions in order to function better in crisis situations. Accordingly, the structure of this paper was conceived, which, in addition to an introduction and concluding remarks, has five short, but thematically complete, units. In the first part, preventive management is seen as a paradigm of the successful management of problems, incidents and crises. In the second and third parts, the influence of the principles of quality management and the principles of risk management on the prevention of a crisis, as well as their cooperation, effectiveness and synergistic effects are discussed. The fourth part analyses the key processes of change and conflict management in terms of crisis prevention. In the fifth part, an effective, complete and comprehensive crisis prevention model based on quality management, risk management and change management is created, with the primary goal of achieving sustained success in all business conditions. Bearing in mind that the processes and consequences of the Coronavirus pandemic have still not been completed or become clear, the concluding remarks identify certain messages and lessons that could have been learned in its initial stages.
\end{abstract}

Keywords: Preventive Management, Crisis, Quality Management Principles, Risk Management Principles, Change Management, a Model of Crisis Prevention, Coronavirus Pandemic

JEL Classification: M10, M19, M54
${ }^{*}$ Central Bank of Montenegro, Podgorica, Montenegro

Email: radoica.luburic@cbcg.me 


\section{Introduction}

While the world has been changing rapidly and dramatically in recent decades, many organisations and states, as well as the entire population, have not reacted in a timely and adequate manner to the numerous threats and dangers that were increasing every day. Political, economic and security upheavals, such as terrorist attacks, limited conflicts and wars, as well as all kinds of natural disasters and threats (Fabris, 2020) should have been a serious warning to all of humanity. We should not forget, for example, the terrorist attacks in America in 2001, the world financial crisis that broke out in 2008, or the devastating tsunami in Japan in 2011.

In recent decades, the world has faced a number of epidemics and pandemics, such as HIV, bird flu, mad cow disease, SARS, swine flu H1N1, MERS, and Ebola. However, nothing has shaken the world as did the emergence of the Coronavirus pandemic, in early 2020. As the consequences of this pandemic became ever more dramatic, the level of concern from scientists, experts, the media, as well as the general public, grew enormously. All the mysteries and controversies that accompany this pandemic will only truly come to light when the dust has settled, the crisis subsides and things calm down.

Historically, epidemics and pandemics are "long-lasting phenomena" that date back to the distant past, and are caused by both human and natural factors. Thus, people have always faced epidemics and pandemics that have claimed a huge number of human lives and some of them have led to the collapse of entire economies and states. Many researchers claim that, with the exception of famine, which has been "humanity's worst enemy" for thousands of years (Harari, 2018) nothing has killed as many people as viruses, bacteria and parasites, neither all wars added together, nor natural disasters like earthquakes or volcanic eruptions (Walsh, 2020). Epidemics and pandemics have changed and shaped not only the course of history over the centuries, but also, to a great extent, the whole of humanity - in demographic, sociological, cultural, religious, political, economic, security, military, state-legal and every other sense (Šćekić, (2020), Steinmetz, (2020), Luburić, Fabris, and Sekulović, (2020)).

Although epidemics and pandemics have had a very devastating effect in the past, the lack of transport and population movement had been one of the key factors in slowing down, limiting, and even preventing the spread of any virus on a global scale. Unlike all previous epidemics and pandemics, this pandemic infected almost every country in the world in just a few months, significantly paralysed all social and economic activities, changed the way people live and work and, 
unfortunately, has already taken a huge number of human lives. Many scientists warn that this pandemic poses such a global and total threat, that it has already caused "tectonic" disturbances in many areas of social life, with long-term and unforeseeable consequences.

\section{1. "Risk-based thinking" and Preventive Management as a Paradigm for the Successful Solving of Problems, Incidents and Crisis}

The effectiveness and efficiency of preventive management depends on a number of factors, and above all, on timely and adequate "risk-based thinking" and overall risk management. The main purpose of "risk-based thinking" is preventive management, which contributes not only to preventing the occurrence of risk, but also to finding opportunities for improvement and innovation. The concept of "risk-based thinking" makes a strategic contribution to the quality management system, because it puts people at the very centre of change and preventive management (Luburić and Perović, 2020).

"Risk-based thinking" allows the organisation to identify those factors that may influence the emergence of potential risks, as well as potential threats that could stand in the way of set goals. This thinking allows the organisation to establish a system of preventive management in order to minimise any negative effects and make the most of opportunities when they occur. It should be borne in mind, however, that all opportunities, even the most favourable, carry with them certain risks. Risk, in itself, always brings with it effects of uncertainty, which can lead to both positive and negative consequences.

The basic purpose of preventive management is constant, complete and comprehensive thinking about both potential risks and potential opportunities, which is itself essential for achieving an effective management system (ISO/TS 9002, pp. 10-12). This effectiveness is achieved through the operation of a number of complex influences, of which five relevant groups stand out: quality management, risk management, change management, taking advantage of opportunities and preventing undesirable results. These five groups of influencing factors, as shown in Figure 1, operate in the context of achieving an effective preventive management system. 
Figure 1: Key processes of preventive management

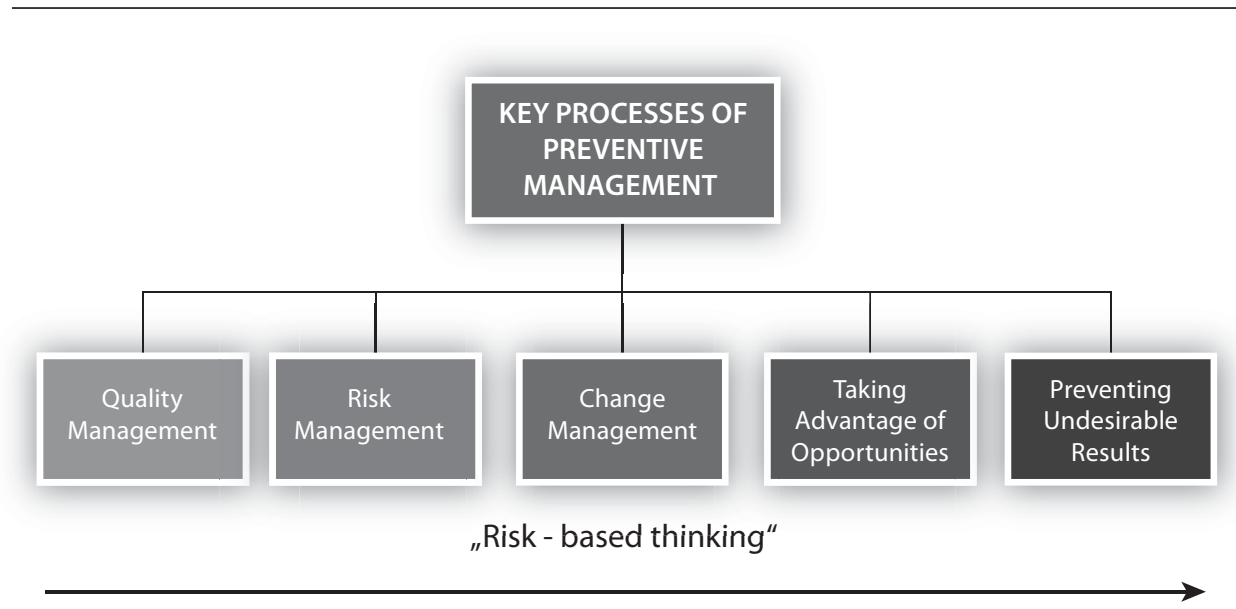

In turbulent and dramatic times such as these caused by the Coronavirus pandemic, without an effective management system based on preventive management, quality management and risk management, as well as change management, there is neither the certain survival of the organisation nor too many opportunities for sustained development. Basically, it is difficult to expect that the effectiveness and efficiency of preventive management in an organisation will be at a high level in crisis situations, if it was not at a high level in stable conditions. Accordingly to meet that challenge, "managers should first understand their vulnerabilities and then consider a number of steps-some of which they should have taken long before the pandemic struck" (Shih, 2020, p. 84).

Let us remember that old folk saying: Prevention is better than cure! This saying did not come into being by chance, neither in one day nor in one year. It sprung from life, and has been confirmed and reconfirmed over the centuries. Experience has shown us that it is much better to solve problems and incidents in a timely and adequate manner, than to allow them to turn into a crisis, with all the uncertainty that it brings with it. Therefore, it is absolutely essential to take preventive action on problems and incidents so that they do not escalate into a crisis.

Although we live with problems, and increasingly with incidents and crises, it is not easy to define them, neither at a theoretical nor at a practical level. What then are problems? Simply put, problems are visible and invisible hurdles encountered on the way to achieving goals. Incidents are, however, the consequences of problems that have not been resolved in a timely and adequate manner. According to 
ISO 22301:2019, Security and resilience - Business continuity management systems - Requirements, an incident is defined as "an event that can be, or could lead to, a disruption, loss, emergency or crisis" (ISO 22301:2019, p. 3).

What then is a crisis? A crisis is most often the result of accumulated problems and incidents that have not been successfully resolved in a timely manner. British Standard 11200:2014, Crisis management - Guidance and good practice, defines a crisis as an "abnormal and unstable situation that threatens the organisation's strategic objectives, reputation or viability” (BS 11200:2014, p. 2).

A crisis calls into question the overall sustainability of the organisation, the fate of its employees, the competitiveness of its processes, products and services, and in particular, its reputation. Therefore, it is essential that preventive action to tackle problems and incidents is undertaken before they are able to grow into a crisis. In order to achieve this, it is important, among other things, to understand and lay out the conceptual and practical relationship between problems, incidents and crises, as well as their key characteristics.

As shown in Figure 2, six basic characteristics of problems, incidents and crises have been analysed, with a particular focus on their key distinctions, which are significant for preventive action. When it comes to Predictability, it can be seen that problems are foreseeable, incidents are usually foreseeable, while crises are unique, rare, some elements are foreseeable and others unforeseeable. At their Onset, problems are manifestations of ongoing hurdles; incidents are gradual failures with warning signs and are caused by unresolved problems. Crises, however, are often sudden and without warning because the system of prediction, recognition and early warning did not work. They are often an escalation of incidents.

When we take a look at Urgency and Duration, problems are mainly urgent and short term, incidents are usually urgent and of limited term, while crises are of great urgency and followed by long term uncertainty. In regards to the characteristic of Understanding and Impact, problems are well understood and their impact is limited. Incidents are usually understood and can be applied to predefined responses, although their impact can potentially be widespread. A crisis is different because of its complexity and its impact maybe difficult to assess and fully comprehend. It may also affect the entire organisation. When it comes to Media Coverage, problems are not generally covered by the media, and incidents attract little media attention. A crisis attracts significant public and media interest. It is important, however, to keep in mind that some of the coverage in the media and on social networks might be partly inaccurate or misleading and this could quickly deepen the crisis. 
Figure 2: Key characteristics and distinctions between problems, incidents and crises

\begin{tabular}{|c|c|c|c|}
\hline CHARACTERISTICS & PROBLEMS & INCIDENTS & CRISES \\
\hline Predictability & Foreseeable & Usually foreseeable & $\begin{array}{l}\text { Unique, rare, some } \\
\text { elements are foreseeable } \\
\text { and others unforeseeable }\end{array}$ \\
\hline Onset & Ongoing hurdles & $\begin{array}{l}\text { Gradual failures with } \\
\text { warning signs }\end{array}$ & $\begin{array}{l}\text { Often sudden and without } \\
\text { warning because the } \\
\text { system of prediction, } \\
\text { recognition and early } \\
\text { warning did not work. } \\
\text { Escalation of incidents. }\end{array}$ \\
\hline $\begin{array}{l}\text { Urgency and } \\
\text { Duration }\end{array}$ & $\begin{array}{l}\text { Mainly urgent and } \\
\text { short term }\end{array}$ & $\begin{array}{l}\text { Usually urgent and } \\
\text { of limited term }\end{array}$ & $\begin{array}{l}\text { Great urgency and long } \\
\text { term uncertainty }\end{array}$ \\
\hline $\begin{array}{l}\text { Understanding } \\
\text { and Impact }\end{array}$ & $\begin{array}{l}\text { Problems are } \\
\text { understood and } \\
\text { their impact is } \\
\text { limited }\end{array}$ & $\begin{array}{l}\text { Incidents are usually } \\
\text { understood and } \\
\text { can be applied to } \\
\text { predefined responses. } \\
\text { Their impact can } \\
\text { potentially be } \\
\text { widespread. }\end{array}$ & $\begin{array}{l}\text { Because of its complexity, } \\
\text { its impact maybe difficult } \\
\text { to assess and fully } \\
\text { comprehend. } \\
\text { May affect the entire } \\
\text { organization. }\end{array}$ \\
\hline Media Coverage & $\begin{array}{l}\text { Not covered by } \\
\text { the media }\end{array}$ & $\begin{array}{l}\text { Generally attracts } \\
\text { little media } \\
\text { attention. }\end{array}$ & $\begin{array}{l}\text { Significant public and } \\
\text { media interest. } \\
\text { Some coverage in the } \\
\text { media and on social } \\
\text { networks might be partly } \\
\text { inaccurate or misleading } \\
\text { and can quickly deepen } \\
\text { the crisis. }\end{array}$ \\
\hline $\begin{array}{l}\text { Manageability } \\
\text { through } \\
\text { established } \\
\text { plans and } \\
\text { procedures }\end{array}$ & $\begin{array}{l}\text { Ad hoc solutions } \\
\text { are often } \\
\text { applicable }\end{array}$ & $\begin{array}{l}\text { Incidents can be } \\
\text { resolved by applying } \\
\text { appropriate, } \\
\text { predefined } \\
\text { procedures and } \\
\text { planned resources. }\end{array}$ & $\begin{array}{l}\text { Crises are rarely resolvable } \\
\text { through the application } \\
\text { of predefined procedures } \\
\text { and plans. } \\
\text { They demand changes and } \\
\text { innovations, as well as a } \\
\text { flexible, creative, strategic } \\
\text { and sustained response. } \\
\text { To successfully resolve a } \\
\text { global crisis, an adequate } \\
\text { global response is } \\
\text { essential. }\end{array}$ \\
\hline
\end{tabular}

Modified from: BS 11200:2014, Crisis management-Guidance and good practice, p. 4.

The characteristic of Manageability through established plans and procedures is the very essence of successful crisis prevention. For solving problems, ad hoc solutions are often applicable, while incidents can be resolved by applying appropriate, predefined procedures and planned resources. On the other hand, crises are rarely resolvable through the application of any predefined procedures and 
plans. They demand changes and innovations, as well as a flexible, creative, strategic and sustained response. We have learned from the Coronavirus pandemic that in order to successfully resolve a global crisis, an adequate global response is always essential. From all of the above, it follows that it is incomparably better to adequately resolve problems and incidents on time, rather than to grapple with a crisis and all the complexity, uncertainty and anxiety that it brings with it.

Crisis management is a very complex process that requires a great deal of interdisciplinary and multidisciplinary knowledge, much of which comes from the areas of quality management, risk management and change management (Perović, Luburić, Fabris, and Šarović (2019). These elements are of special importance, which is shown in the following chapters.

\section{Quality Management Principles and Crisis Prevention}

According to the international standard ISO 9000:2015, Quality management systems - Fundamentals and vocabulary, quality management is based on seven principles, as shown in Figure 3: Customer Focus, Leadership, Engagement of People, Process Approach, Improvement, Evidence-based Decision Making, and Relationship Management (ISO 9000:2015, pp. 3-9) (Luburić, 2015).

Customer Focus is one of the most important principles of quality management and one of the key factors for business success. The special importance of this principle is that in this area all the other principles of quality management are integrated, as well as the activities of all employees in the organization. Understanding the current and future needs of customers contribute to overall success as together they are the best interpreters and followers of the mission and vision of the organisation.

The principle of quality management, Leadership, is the key to the successful management of change, the prevention of a crisis and the achievement of the sustained success of each organisation. The role of the leader in achieving success is also highlighted by the ISO 9000:2015 standard, which states that, "leaders at all levels establish unity of purpose and direction and create conditions in which people are engaged in achieving the organisation's quality objectives" (ISO 9000:2015, p. 4). Leaders make it possible to adequately take into account the external and internal context of the organisation, to always be aware of the situation in which it is located, to balance and affect its policies, goals, strategies, processes and resources, which are of particular importance for crisis prevention and achieving sustained success. 
Figure 3: Quality Management Principles in terms of Crisis Prevention

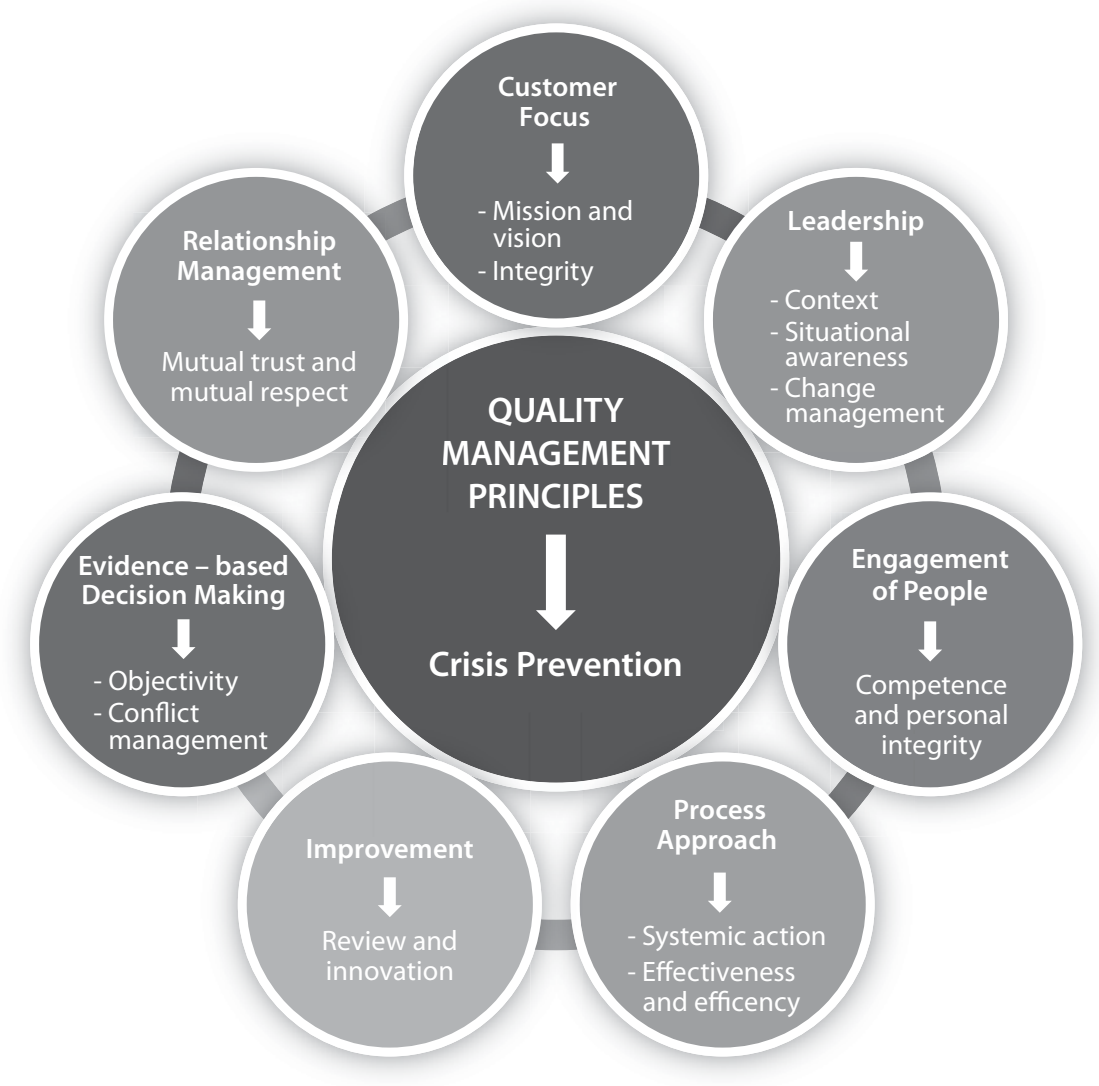

The principle Engagement of People rightly emphasizes that people are the most important factor for achieving success and the very essence of an organisation itself. Only the full engagement of employees guarantees a safe path to achieving sustained success. According to ISO 9000:2015, "competent, empowered and engaged people at all levels throughout the organisation are essential to enhance the organisation's capability to create and deliver value" (ISO 9000:2015, p. 5). It is therefore essential those employees possess the knowledge and the level of personal integrity required to be competent, and that they are also empowered to make decisions and organise themselves to solve problems. This approach is based on the logic that employees not only live with problems, but also with the opportunities for improvement. They are in the best possible position to not only identify the causes of the problem, but also to find the best solutions and ways to further improve, which is crucial for the prevention of a crisis. 
The principle, Process Approach, is based on the concept that "consistent and predictable results are achieved more effectively and efficiently when activities are understood and managed as interrelated processes that function as a coherent system" (ISO 9000:2015, p. 6). It is through the creation of this system that an organisation produces results and this enables it to optimise its performance. Process and system management as a whole can be achieved by using the PDCA methodology (Plan - Do - Check - Act), with special focus on "risk-based thinking" in order to take advantage of opportunities and prevent undesirable results, which is key to preventing a crisis (ISO 9001:2015, p. vii) (Luburić and Perović, 2020).

A special place and role in management is rightly given to the principle Improvement, because there can be no achievement of sustained success without continual improvement. In the international standard ISO 9000:2015, it is stated that "successful organisations have an ongoing focus on improvement", which is explained by the rationale that continual improvement is "essential for an organisation to maintain current levels of performance, to react to changes in its internal and external conditions and to create new opportunities" (ISO 9000:2015, pp. 6-7). In order for the organisation to be sustainably successful and to effectively and efficiently be able to prevent a crisis, it is necessary to continually review, improve and further innovate its processes, products and services.

The principle of Evidence-based Decision Making is explained in the standard as "decisions based on the analysis and evaluation of data and information is more likely to produce desired results" (ISO 9000:2015, p. 7). This statement is explained by the fact that decision-making can be a complex process and it always involves some uncertainty and subjectivity. It is important to take into account cause and effect relationships and potential unintended consequences. Facts, evidence and data analysis lead to greater objectivity and confidence in decision making. Decisions that are neither well understood nor accepted as correct often lead to destructive conflict. Evidence-based decision making and its objectivity greatly assist in the process of change and conflict management and preventing a crisis.

Relationship Management, as a principle of management implies that the building of mutual trust and mutual respect not only between the employees in the organisation, but also with all partners, is a precondition for the successful management of changes and conflicts. Crisis prevention and sustained success are better achieved when the organisation effectively manages its relationships with all interested parties. In the international standard ISO 9000:2015, it states that "for sustained success, organisations manage their relationships with relevant interested parties, such as providers", because they significantly influence the optimisation of the performance of the organisation (ISO 9000:2015, p. 8). 
All the aforementioned principles of quality management, both individually, and in total, significantly contribute to the prevention of crisis. They form the basis for creating a model of crisis prevention and their effectiveness significantly contributes to improving the overall performance of organisations.

\section{Risk Management Principles and Crisis Prevention}

The international standard, ISO 31000:2018, Risk management - Guidelines, explains that the purpose of risk management is "the creation and protection of value", and that means it continually improves the performance of the organisation, encourages innovation and supports the achievement of objectives (ISO $31000: 2018$, p. 2). According to this standard, risk management is based on eight guiding principles: Integrated, Structured and Comprehensive, Customised, Inclusive, Dynamic, Best Available Information, Human and Cultural Factors, and Continual Improvement (ISO 31000:2018, pp. 3-4). These principles are fundamental for effective and efficient risk management. Risk Management Principles enable an organisation to manage the effects of uncertainty on its objectives, which is of particular importance in preventing crisis.

The principle Integrated, explains that risk management is an integral part of all organisational activities that enables the timely and adequate solving of the causes of problems and incidents, which is crucial in the processes of crisis prevention. The principle Structured and Comprehensive is an approach to risk management that contributes to consistent and comparable results, that plays a significant role in solving problems and incidents, as well as in the prevention of a crisis, by systematically dealing with its causes.

The principle Customized, points to the importance that risk management adapts to each particular case and that it is aligned with the external and internal context of the organization, in order to timely and adequately affect the causes of problems and incidents. The principle Inclusive, implies the appropriate and timely involvement of stakeholders and enables their thinking, attitudes and perceptions to be considered, which improves awareness and ensures better informed risk management, and thus helps prevent the escalation of problems and incidents.

The principle Dynamic indicates that risks can appear, alter or disappear as the external or internal contexts change. Risk management has to predict, recognise and respond to these changes in a timely and appropriate manner, which can greatly minimise the potential impact of problems and incidents. The principle 
Best Available Information indicates that risk management explicitly takes into account all the limitations and uncertainties associated with information and expectations. It helps to ensure that all this information should be timely, clear and available to all relevant stakeholders, which is essential for the resolution of problems and incidents, as well as for the prevention of a crisis.

\section{Figure 4: Risk Management Principles in terms of Crisis Prevention}

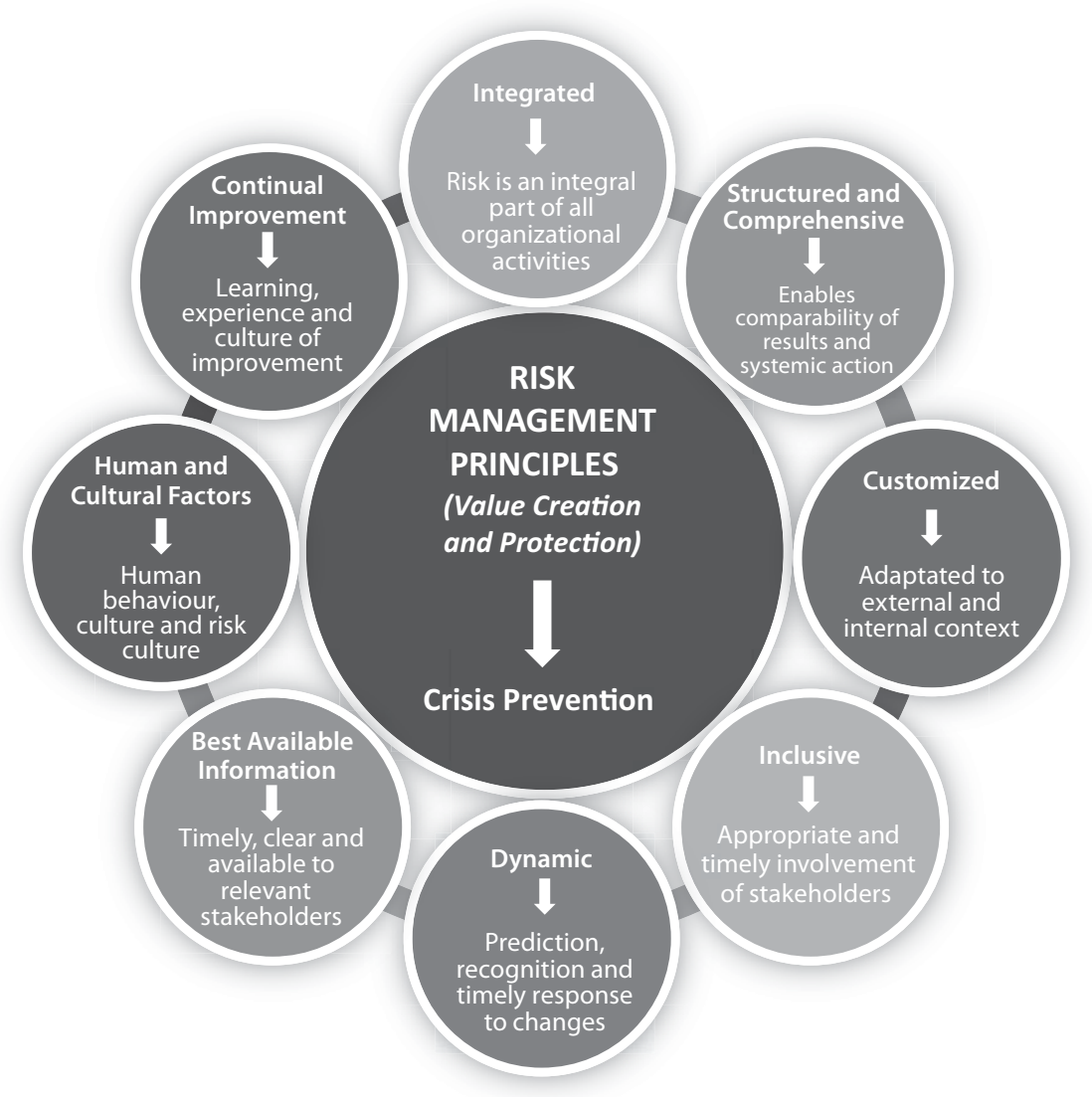

The principle Human and Cultural Factors indicates that human behaviour, culture and the development of a risk culture significantly influence the effectiveness of the risk management process at all levels of the organisation (Power and Mikes, 2020). It greatly influences the nature of the decisions made in order to successfully solve problems and incidents and the timely prevention of a crisis. 
The international standard, ISO 31000:2018, explains the principle Continual Improvement, in the following way, "Risk management is continually improved through learning and experience" (ISO 31000:2018, p. 4). This is based on the idea that through learning and experience a culture of improvement is developed that then becomes a generator of effective crisis prevention.

To continually improve processes and systems, as well as all segments and levels of the management of the organisation, ISO standards, as already mentioned, use the PDCA methodology as shown in Figure 5.

The process of continual improvement shown in the previous figures demonstrates how the PDCA methodology works - a completed cycle has to lead to the start of a new cycle, with a new plan, new information and the new application of acquired knowledge and experience from previous cycles. Each subsequent cycle has an improved plan, improved processes and activities, improved checks and analysis as well as other new improvements. Simply put, each new cycle represents an "improvement of improved improvements".

It should be noted that both the PDCA methodology and the management concept of "risk-based thinking" contribute to taking advantage of opportunities and preventing undesirable results, which are of particular importance for crisis prevention. In the conditions of growing uncertainties and more frequent crises, organisations will be forced to live with crisis and "crisis-based thinking".

Figure 5: PDCA methodology of continual improvement ("improvement of improved improvements")
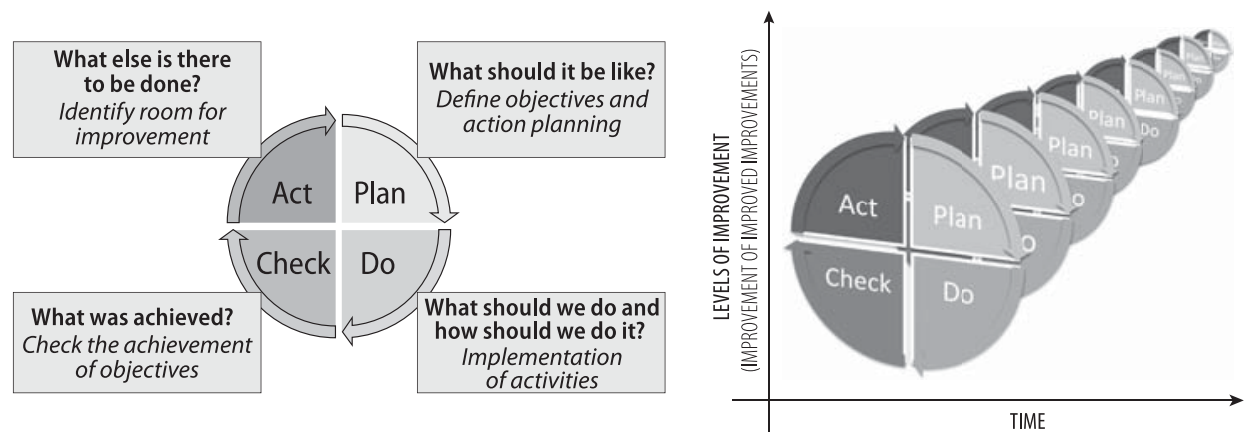


\section{Change and Conflict Management in terms of Crisis Prevention}

The challenges and consequences that arise when a crisis has not been successfully prevented can be clearly seen through numerous examples from the recent global financial and banking crisis (Fabris, 2018). The financial crisis that spread across the world in the middle of 2008 was to a significant degree the product of unsuccessful change management. The financial, especially the banking, sector, blinded by enormous profits, did not predict, anticipate, create and innovate in time. In one word it did not adequately manage the changes. When the crisis had already begun, stereotypical plans were activated, already prepared for action in emergency situations, but without any significant results. Many of the preventive early recognition and warning mechanisms that existed earlier did not timely detect the dangers. This lack of effective management of change led to a crisis, just as many failings in crisis prevention have happened in the current pandemic crisis.

Starting from the fact that everything is a system made up of subsystems that are in constant interaction with the changing environment, it can be concluded that everything is subject to change. The key problem, however, is not in the change, if it is implemented in a timely and adequate manner, but in the fact that the subsystems in that process are often not synchronised. The lack of synchronisation leads to destructive conflicts and the disintegration of the system, which is initially manifested by problems and incidents, and possibly later by a crisis.

Figure 6: Key processes of change and conflict management in terms of crisis prevention

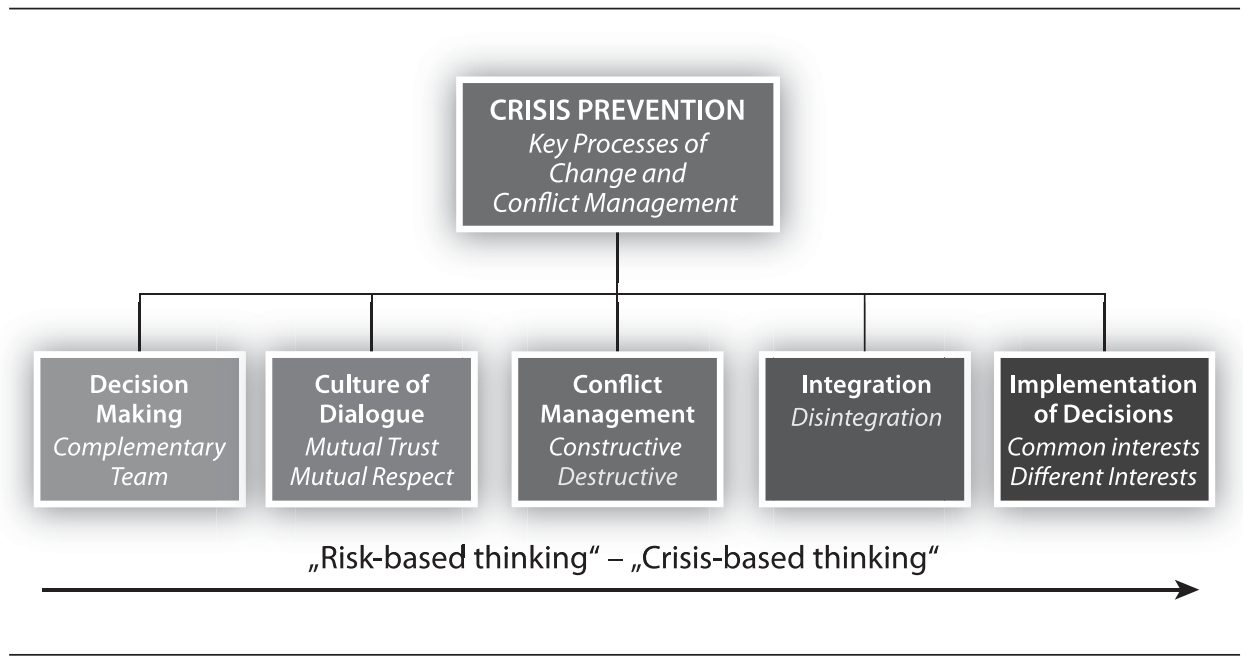


Successful change management, therefore, implies successful conflict management, which is not possible in an organisation without mutual trust and mutual respect. Mutual trust and mutual respect are one of the key factors for successful change management and the success of any organisation. The faster and more radical the changes, the more complex the problems become, so mutual trust and mutual respect become more and more necessary. Good decisions are both made and implemented by a complementary team able to harmonise both common and different interests. This is all integrated into a synergistic trinity - quality management, risk management and change management.

Timely and adequate management of change is one of the key goals of effective management. Due to the dramatic acceleration of change, it is not easy to manage an organisation even in stable, let alone in crisis conditions like the current pandemic. Nothing can "shake up" an organisation as much as the challenges that arise from accelerating change, for which top management is not ready and for which there are no timely and adequate responses. If, however, organisations are managed on the principles of quality management and the principles of risk management, it will be possible to successfully manage change and conflicts. The philosophy of change management, as well as the philosophy of quality management and risk management, is primarily directed towards preventive management and the sustained success of the organisation.

\section{Creating an Effective Model of Crisis Prevention}

In one of his earlier pieces of work, the author of this paper created a model of crisis prevention that provoked a great deal of scientific and professional interest (Luburić, 2019). However, given that this model was created while the day was still clear and the sun was "shining", and not in the conditions of the dramatic storm caused by the Coronavirus pandemic, it is now necessary to re-examine, improve and innovate it.

In the previous parts of the research, the key aspects that influence the timely and adequate resolution of problems and incidents have been analysed, which are the prerequisite for successful prevention of a crisis. In order for organisations to solve problems and incidents in this way, and thus prevent a crisis, effective and efficient quality management, risk management and change management are essential, as well as a mastery of the necessary knowledge and skills, which is neither simple nor easy. Numerous complex factors influencing quality management, risk management and change management, integrated into a coherent 
and consistent system, are the basis for creating the model of crisis prevention, as shown in Figure 7.

\section{Figure 7: The model of crisis prevention}

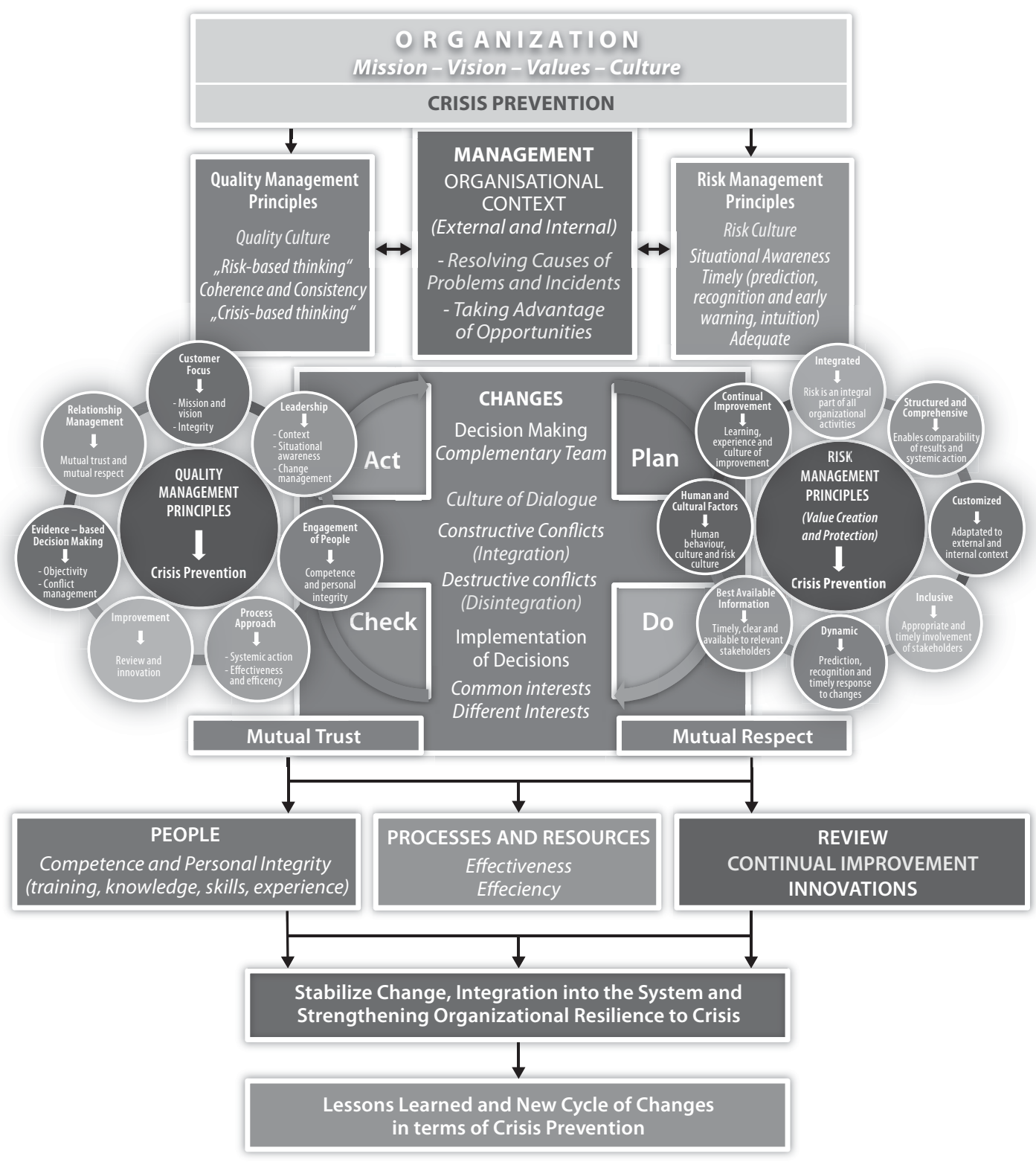


Standard ISO 9004:2018, Quality management - Quality of an organization Guidance to achieve sustained success, emphasises the systematic improvement of the overall performance of the organisation. By this standard, an organisation is defined by its identity and context. The identity of an organisation is determined by its characteristics, based on its mission, vision, values and culture (ISO 9004:2018, p. 5).

Top management bears the greatest responsibility for all the successes and failures of the organisation. Its task is to continually monitor and analyse the external and internal context of the organisation, in order to ensure success. Management must create the necessary conditions that enable employees to solve the causes of problems and incidents in a timely and adequate manner, to prevent the emergence of a potential crisis.

All the employees in the organisation have to thoroughly analyse whether the problems and incidents they face are the result of mistakes that have been made, or are the result of inadequate and unsuccessful processes. Many studies have shown that most problems and incidents actually arise from such processes rather than from any individual errors. Instead of ineffective and exhausting efforts to deal with errors individually, it is essential to constantly review and improve the processes that constitute the root causes of the problems and incidents, so that they are not repeated. The essence is, in fact, not only in solving the causes of problems and incidents, but also in finding and taking advantage of opportunities.

In this model, Quality Management Principles and Risk Management Principles work in tune, harmoniously, synchronously and synergistically. The application of these principles not only contributes to the more effective and efficient achievement of its mission, vision, values and culture, but also significantly raises awareness about the opportunities opened up by their full implementation within the organisation itself. As we have already seen, there are many synergistic effects that the implementation of these principles brings to organisations to assist in the prevention of a crisis Luburić, 2019). Of particular importance is their great influence in changing the way of thinking among all stakeholders. This new way of thinking creates new behaviours and an improved business culture which is more able to successfully prevent a crisis and achieve sustainable success (Luburić, 2018).

The Quality Management Principles cannot be fully effective and efficient without a developed quality culture and "risk-based thinking", and in crisis situations without "crisis-based thinking". In the same way, the Risk Management 
Principles require a developed risk culture and the timely prediction, recognition and early warning of risks that can be managed adequately. A developed quality culture and risk culture are a great source of strength for the organisation, just as it can be a major cause of weakness to be without them (Luburić, 2017).

As was stated earlier, there cannot be successful crisis prevention without the successful management of change and conflict. Changes must first be successfully implemented under stable conditions in order that they can be used in situations of the potential escalation of problems and incidents (Luburić, 2013). There cannot be successful change management without a developed culture of dialogue and this cannot exist without mutual respect and mutual trust within the organisation. A culture of dialogue actually encourages constructive conflicts that have an integrative character and are desirable for any organisation, unlike destructive conflicts that spur disintegration. In all of the above, the role of top management and the decisions it makes are of crucial importance. Effective decision making and their efficient implementation requires the work of a complementary team that shares common interests, not only in the short term, but also in the longer term (Adižes, 2011).

As shown in Figure 7, the supporting pillars of the created crisis prevention model are people, processes and resources, as well as review, continual improvement and innovation. For the successful management of any organisation, and consequently for the successful prevention of a crisis, the employees play the most important role and they must not only be competent to carry out their tasks, but must also have personal integrity. The competence of employees is measured by their training, their knowledge, skills and experience, and personal integrity by their professionalism and responsible attitude towards work, and their persistent dedication and loyalty to the organisation and its mission, vision, values and culture.

As already mentioned, it is very important to implement changes, but it is even more important to stabilise the changes and integrate them into the system. Only in this way can the organisation's resilience to the crisis be effectively and efficiently strengthened. The process is, however, not completed, but continues with a new cycle of change with lessons learned and new review, improvements and innovations. It is a spiral process that has its own life and its own life cycles.

The created model of crisis prevention is conceptually original, operationally functional, and flexible, comprehensive and universal. It is completely open to further review, improvement and innovation, which gives it special value. It is applicable in both stable conditions and in the dramatic circumstances of global and total risks, such as the Coronavirus pandemic and similar crises. 


\section{Concluding Remarks}

\section{Crisis Prevention and the Coronavirus Pandemic - Initial Messages and Lessons}

Although crisis situations are by their nature a "race against time", preventive action does not lose its significance even then. On the contrary, it is precisely in crisis situations that the most important thing is to solve burning problems, do not be late in taking action and do not miss an opportunity.

If organisations are able to effectively and efficiently master quality management, risk management and change management in stable conditions, they will be much more successful in implementing preventive management and in crisis situations.

Employees will know and be able to employ both risk-based and crisis-based thinking in a timely and adequate manner to better predict and recognise potential crisis and to interpret early warning signals more completely and comprehensively, and, at the same time be more aware of the situation they find themselves in.

In conditions of increasing temptations and more frequent crises, employees will learn to live with crisis and to think on the basis of crisis. In a word, they will be more ready to face the crisis, regardless of all the challenges and uncertainties.

Just as everything has its two sides, so this pandemic, with all the devastating consequences it brings with it, can also be a real opportunity for overall review, improvement and innovation.

This pandemic can also be an opportunity to look at ourselves, our actions and behaviour, standards and moral values that we have lost somewhere, an opportunity to turn more to family, friends and benefactors, to realign our life priorities, to appreciate and preserve our health much more, as well as the natural environment on which everything depends.

In crisis management, the most important thing is not to let the crisis manage us - but to let us manage the crisis. 


\section{References}

1. Adižes, K. I. (2011). Adižes o menadžmentu, Beograd: HESPERIAedu.

2. British Standards Institution (2014). BS 11200:2014, Crisis managementGuidance and good practice, London: BSI Standards Limited.

3. Fabris, N. (2018). Challenges for Modern Monetary Policy. Journal of Central Banking Theory and Practice, 7(2), pp. 5-24.

4. Fabris, N. (2020). Financial Stability and Climate Change, Journal of Central Banking Theory and Practice, 3(1), pp. 27-43.

5. Harari, N. J. (2018). Homo deus: kratka istorija sutrašnjice. Novi Sad: Laguna.

6. Institute of Risk Management (2018). A Risk Practitioners Guide to ISO 31000:2018, Review of the 2018 version of the ISO 31000 risk management guidelines and commentary on the use of this standard by risk professionals, London: Institute of Risk Management.

7. International Organization for Standardization (2015). ISO 9000:2015, Quality management systems - Fundamentals and vocabulary, Geneva: International Organization for Standardization.

8. International Organization for Standardization (2015). ISO 9001:2015, Quality management systems - Requirements, Geneva: International Organization for Standardization.

9. International Organization for Standardization (2016). ISO/TS 9002:2016, Quality management systems - Guidelines for the application of ISO 9001:2015, Geneva: International Organization for Standardization.

10. International Organization for Standardization (2018). ISO 31000:2018, Risk management - Guidelines. Geneva: International Organization for Standardization.

11. International Organization for Standardization (2018). ISO 9004:2018, Quality management - Quality of an organization - Guidance to achieve sustained success, Geneva: International Organization for Standardization.

12. International Organization for Standardization (2019). ISO 22301:2019, Security and resilience - Business continuity management systems Requirements. Geneva: International Organization for Standardization.

13. Luburić, R. (2013). Challenges in Change Management in Central Banks (Based on a systemic and process approach to Total Quality Management and Operational Risk Management), Journal of Central Banking Theory and Practice, 2(2), pp. 35-49.

14. Luburić, R. (2015). Quality Management Principles and Benefits of their Implementation in Central Banks, Journal of Central Banking Theory and Practice, 4(3), pp. 91-121. 
15. Luburić, R. (2017). Quality Culture and Risk Culture in terms of more effective management, V International Conference, Quality System Condition for Successful Business and Competitiveness, Kopaonik, pp. 11-19.

16. Luburić, R. (2018). Creating a new model of managing change based on Quality Management Principles and Risk Management Principles, ResearchGate, pp. 1-16.

17. Luburić, R. (2019). A Model of Crisis Prevention (Based on managing change, quality management and risk management), Journal of Central Banking Theory and Practice, 8 (2), pp 33-49.

18. Luburić, R., Fabris, N., Sekulović, R. (2020). Pandemija koronavirusa $i$ upravljanje operativnim rizikom centralnih banaka, 22. nacionalni i 8. međunarodni naučno stručni skup, Kopaonik.

19. Luburić, R., Perović, J. M. (2020). “Razmišljanje zasnovano na riziku u funkciji ojačavanja principa menadžmenta kvalitetom”. Kvalitet \& izvrsnost, Godina IX, Broj 7-8, Beograd, pp. 15-18.

20. Luburić, R., Perović, J. M. (2020). “Razmišljanje zasnovano na riziku” kao novi koncept preventivnog upravljanja. Kvalitet \& izvrsnost, Godina IX, Broj 9-10, Beograd, pp. 24-29.

21. Luburić, R. (2019). Principi menadžmenta kvalitetom i menadžmenta rizikom u funkciji prevencije krize. Kvalitet \& izvrsnost, Broj 3-4, FQCE, Beograd, pp. 36-41.

22. Mikes, A. (2020). Values at Risk, In the book Beyond bad apples, Risk Culture in Business. Cambridge University Press.

23. Perović, J. M., Luburić, R., Fabris, N., Šarović, D., (2019). Kvalitet $i$ upravljanje krizom, 21 nacionalni i 7 međunarodni naučno stručni skup "Sistem kvaliteta uslov za uspešno poslovanje i konkurentnost", Kopaonik, pp. 61-68.

24. Power, M. (2020). Risk Culture and Information Culture: Why an 'Appetite for Knowledge' Matters. In the book Beyond bad apples, Risk culture in business, Cambridge University Press.

25. Shih, C. W., Global Supply Chains in a Post-Pandemic World, Harvard Business Review, September-October 2020, pp. 83-89.

26. Steinmetz, C., (2020), Covid-19, superdiversity, crisis-communication and leadership: lessons to be learned, International Journal of Economics, Business and Management Research, Vol. 4, No. 06, pp. 311-329.

27. Šarović, D., Perović, J. M. (2020). Upravljanje krizom i "razmišljanje zasnovano na riziku”. 22. nacionalni i 8. međunarodni naučno stručni skup, Kopaonik.

28. Walsh, B., (2020). Covid-19: The history of pandemics. BBC Future. 